\title{
Kriminálpszichiátria - elméleti háttér és gyakorlati hasznosítás
}

\section{HALLER József - BELLAVICS Mária Zsóka - BARÁTH Noémi ${ }^{1}$}

\begin{abstract}
Pszichiátriai ismeretekre a rendészet már régóta hagyatkozik, a kriminálpszichiátria azonban mint új tudományág csak mostanában van megszületőben. Ebben a tanulmányban amellett érvelünk, hogy a rendöröknek rendelkezniük kell ismeretekkel ezen a téren - nem azért, hogy pszichiáterré váljanak, hanem hogy jobban végezzék munkájukat. Ezt az indokolja, hogy a mentális zavarok nagyon gyakoriak a bünelkövetők körében, amit a tanulmányba foglalt saját kutatási eredményeink is bizonyítanak. Az alapfogalmak tisztázása után áttekintjük (helyszüke miatt csak nagyon vázlatosan) azokat a rendészeti területeket, amelyekben a pszichiátriai ismeretek segítségére lehetnének a rendörnek, kihangsúlyozva azt, hogy eddigi oktatási tapasztalataink szerint a rendészeti hallgatók fogékonyak az ilyen ismeretek iránt. A rendörök kriminálpszichiátriai ismeretei természetesen nem válthatják ki a pszichiáterek munkáját - ez nem is lenne lehetséges -, de professzionálisabbá tehetik a rendöri munkát.
\end{abstract}

Kulcsszavak: pszichiátria, mentális zavar, fiatalkorú bünelkövetők, rendészettudomány, professzionalizmus

\section{Mentális zavar és büncselekmény}

Egy olyan tudományról fogunk értekezni itt, amely többé-kevésbé mindig jelen volt a rendészettudományokban - már akkor is, amikor még aligha lehetett valódi tudománynak nevezni -, de amely csak az utóbbi egy-két évtizedben vált igazán részévé a rendészettudományi gondolkodásnak. A pszichiátriáról van szó.

\footnotetext{
HALLER József, PhD, dr. habil, az MTA doktora, tanszékvezető, Nemzeti Közszolgálati Egyetem, Rendészettudományi Kar, Kriminálpszichológia tanszék.

Dr. József HALLER, PhD, dr. habil, DSci, University of Public Service, Faculty of Law Enforcement, Department of Criminal Psychology, Head of Department,

https://orcid.org/0000-0002-1953-3726, Haller.Jozsef@uni-nke.hu

Dr. BELLAVICS Mária Zsóka, tudományos segédmunkatárs, Nemzeti Közszolgálati Egyetem, Rendészettudományi Kar, Kriminálpszichológia tanszék, Kriminálpszichológia Kutatómühely.

Dr. Mária Zsóka BELLAVICS, research assistant, University of Public Service, Faculty of Law Enforcement, Department of Criminal Psychology, Criminal Psychology Research Workshop,

https://orcid.org/0000-0002-4678-693X, zsoka.bellavics@gmail.com

BARÁTH Noémi, tudományos segédmunkatárs, Nemzeti Közszolgálati Egyetem, Rendészettudományi Kar, Kriminálpszichológia tanszék, Kriminálpszichológia Kutatómúhely.

Noémi BARÁTH research assistant, University of Public Service, Faculty of Law Enforcement, Department of Criminal Psychology, Criminal Psychology Research Workshop,

https://orcid.org/0000-0002-7491-8063, noemi.emoke@gmail.com
} 
Az állítás első felének igazolásaképpen álljon itt egy idézet egy korában híres és mostanában újra kiadott szerzőpáros eredetileg 1906-ban publikált könyvéből. Amikor az erőszakos bűntettek elkövetőit mintegy osztályozták, Tábori Kornél újságíró és Székely Vladimir, aki nyugállományba vonulásakor Budapest Rendőrfőkapitány-helyettese volt, így ír az egyik típusról: „Aki megfontolva pusztít életet, abnormis legtöbbször a törvényszéki orvosszakértő szemében is. Mániákus erő hajtja, amely áhítja a vért, $s$ nem ismeri borzalmát, habár tény az is, hogy mentül kegyetlenebb s nagyobb a bűn, annál kevésbé szabad és tanácsos azt szívós kritika nélkül betegséggé devalválni." ${ }^{2}$ Amellett, hogy megsejtették annak az agresszió- és erőszaktípusnak a létét, amelyet ma pszichotikusnak nevezünk, ${ }^{3}$ egyúttal megfogalmazták azt a dilemmát is, amellyel ma is küzdünk, nevezetesen a mentális zavar és a büntetőjogi felelősség viszonyához kapcsolódó ambivalens érzéseket.

A „zavart elme” koncepciója mint a bűntettek mozgatórugója régóta jelen van nemcsak a köz-, hanem a tudományos gondolkodásban is. Cesare Lombroso immár 150 éves bűnözői típusleírásait - a bűnügyi antropológia első megnyilvánulásait - is az a gondolat ihlette, hogy a bűntettek elkövetői abnormálisak, aminek külső jelei vannak. ${ }^{4}$ Bár a kutatási eredményeiből logikusan származó következtetések később diszkreditálódtak, lényegében a bűnözés biológiai okait vizsgálta a kor módszereivel, és szellemi öröksége ma is deklaráltan él, egyebek mellett a bűnözés neurobiológiai hátterének kutatásában. ${ }^{5}$ Ma már tudjuk, hogy a bűnelkövetés kockázatát bizonyos biológiai tulajdonságok, például az örökölt gének, az élet során átélt különböző jellegú traumák, és az ezek következtében kialakuló idegrendszeri elváltozások megnövelik, és e kockázatok megtestesítői közé tartoznak azok az állapotok, amelyeket a „mentális zavar” gyűjtőnévvel illetünk.

Elöljáróban le kell szögeznünk, hogy a mentális zavar fogalma nem azonos azzal, amit a köznyelvben „elmebetegségnek” vagy a szaknyelvben értelmi akadályozottságnak neveznek. Ennek mind a bünügyi felelősség, mind a rendészeti vonatkozások szempontjából jelentősége van. Mielőtt azonban a tárgyra térnénk, és egyebek mellett ezt a különbségtételt is részleteznénk, meg kell válaszolunk három egyszerú kérdést, amelyek minden bizonnyal felvetődnek azokban, akik nem járatosak a témában.

\section{Mit nevezünk mentális zavarnak?}

A mentális zavarokkal a pszichiátria tudománya foglalkozik, az orvostudománynak az az ága, amelynek tárgya a kórosan zavart lelkiállapot. A mentális zavarokat két széles

\footnotetext{
Tábori Kornél - Székely Vladimir: A bünös Budapest. Budapest, Tudáspolc, 2014. 91-92.

Philipp M.: Psychotic aggression in the medical emergency service. Medizinische Welt, 30. (1979), 39. 1436-1438.; Barbara McDermott et alii: The accuracy of risk assessment instruments in the prediction of impulsive versus predatory aggression. Behavioral Sciences and the Law, 26. (2008), 6. 759-777.

4 James A. Brussel: Casebook of a crime psychiatrist. New York, Bernard Geis Associates, 1968.

5 Priscilla Savopoulos - Anukka K. Lindell: Born criminal? Differences in structural, functional and behavioural lateralization between criminals and noncriminals. Laterality, 23. (2018), 6. 738-760.
} 
körben használt orvosi kézikönyv listázza és írja le precízen, nevezetesen a Diagnostic and Statistical Manual of Mental Disorders ${ }^{6}$ (Mentális Zavarok Diagnosztikai és Statisztikai Kézikönyve), amelyet az Amerikai Pszichiátriai Társaság gondoz, és a „Classification of Mental and Behavioral Disorders” (A Mentális és Viselkedési Zavarok Osztályozása), amit az Egészségügyi Világszervezet jegyez, és amely része a Betegségek Nemzetközi Osztályozása nevet viselő rendszernek, bár külön kötetben publikálják. ${ }^{7}$ Mindkét kiadvány rendszeresen megújul. E referenciamunkáknak itt most nem a betegségleírásaival, hanem általános koncepciójával foglalkozunk - azokkal az általános jelekkel, amelyek alapján a kórosan zavart és nem zavart lelkiállapotok elkülöníthetők.

A mentális zavar jelenlétének első fontos jele, hogy egy bizonyos érzelem vagy viselkedés ellenállhatatlanul és nem megfelelő helyzetben jelentkezik, vagyis inadekvát az adott helyzetben. Egy-egy példával élve a páni félelem (mint érzelem) inadekvát, ha a környezetben semmilyen veszélyforrás nem azonosítható sem rövid, sem hosszú távon. A dühkitörés (mint viselkedés) inadekvát, ha nincs sem oka (például nem provokálták ki), sem célja (például az illető semmit nem akar elérni általa). Ha egyik vagy másik megjelenik, felmerül a pánik- vagy időszakosrobbanékonyság-zavar gyanúja - csak gyanú, mert ahhoz, hogy mentális zavarnak fogjuk fel, szükséges, hogy gyakran előforduljanak, és megzavarják az illető normális életvitelét. Mind a pánik-, mind az időszakosrobbanékonyság-zavar elvártgyakoriság-kritériuma átlagosan két roham hetente, legalább három hónapon keresztül. Ha ritkábban jelentkeznek, a rohamoknak egy vagy több éven át kell ismétlődniük úgy, hogy annak életviteli következményei legyenek. Aki például pánikzavarban szenved, előbb utóbb kénytelen megváltoztatni életvitelét, például fel kell hagynia az autóvezetéssel, vagy kerülnie kell a nyilvános szereplést, mert a pánik bármilyen helyzetben jelentkezhet, és ideiglenesen cselekvőképtelenné teheti. Akiből gyakran tör ki ellenállhatatlanul az agresszió, annak mind magánélete (például házassága), mind társadalmi státusza (például munkahelye) veszélybe kerül - tehát életviteli nehézségei támadnak. Megjegyezzük, hogy van a mentális zavaroknak egy harmadik nagy osztálya is, a valóságtól való elszakadás (például a pszichotikus állapot), amelynél a zavartság nyilvánvaló, ezért ezt nem szőttük be példáink közé.

A mentális zavarok tehát racionálisan nem magyarázható, ellenállhatatlanul jelentkező érzelmi és/vagy viselkedési megnyilvánulások, amelyek időben tartósak, és megnehezítik az életet. A mentális zavarok két nagy csoportja - az idegrendszeri fejlődési zavarok és a neurodegeneratív betegségekkel járó zavarok - értelmi akadályozottsággal jár, de ez inkább kivétel, mint szabály. Mentális zavarokkal küszködött számtalan múvész, tudós, közéleti személyiség vagy éppen uralkodó - például Viktória, Nagy Britannia királynője, vagy éppen Erzsébet, magyar királyné - anélkül, hogy értelmi képességeik bármilyen formában zavart szenvedtek volna, sőt. Az emberiség sokat köszönhet olyan embereknek, akik valamilyen mentális zavarban szenvedtek.

DSM-5, Diagnostic and Statistical Manual of Mental Disorders, Fifth Edition. Arlington, VA, American Psychiatric Association, 2013.

7. ICD-10 The ICD-10 Classification of Mental and Behavioral Disorders. Geneva, World Health Organization, 1999. 


\section{Miért érdekesek a mentális zavarok rendészettudományi szempontból?}

A mentális zavarokkal elsősorban az orvostudomány foglalkozik; legfontosabb kérdése az, hogy hogyan lehet megszabadítani valakit egy olyan állapottól, amely megnehezíti az életét. Erre a kérdésre számos többé-kevésbé hatékony megoldás született, amelyeket a pszichiáterek naponta alkalmaznak. A kérdéskörnek ez az oldala egyáltalán nem vagy csak nagyon közvetve kötődik a rendészettudományhoz, és itt nem foglalkozunk vele.

Számunkra nagyobb érdeklődésre tarthat számot az a felvetés, hogy a mentális zavar a búnelkövetés kockázati tényezője. Ezt a kérdést sokszor megvizsgálták mind retrospektív, mind prospektív tanulmányokban. A retrospektív vizsgálatok a bủnelkövető mentális állapotát vizsgálják meg, hogy visszakövetkeztessenek a búntettre. Egy híres tanulmány például kimutatta, hogy kaliforniai halálraítélteknek - valamenynyi többszörös gyilkos - legkevesebb három mentális zavara és egy neurológiai betegsége volt egyidejúleg, ${ }^{8}$ pedig azoknak a mentális zavaroknak a száma, amelyeknek jelenlétét vizsgálták, igencsak korlátozott volt - tehát a vizsgálat korántsem volt teljes. A prospektív vizsgálatok kiindulópontja a diagnózis felállítása: ezt követően vizsgálják a bủnelkövetést olyan embereknél, akik a diagnózis felállítása előtt nem követtek el bűntetteket. Egy híres tanulmányban például csaknem 25 ezer embert vizsgáltak meg, és kimutatták, hogy akiknél depressziót diagnosztizáltak, háromszor gyakrabban követtek el erőszakos búncselekményeket a diagnózis felállítása után (emberölést, szexuális bűncselekményeket, rablást, gyújtogatást stb.), mint azok, akiknél depressziót nem állapítottak meg. ${ }^{9} \mathrm{~A}$ búntettek elkövetésének kockázati tényezői nyilván fontos kérdései a rendészettudománynak, és elméleti jelentősége mellett gyakorlati következményei vannak, például a bűnismétlési kockázat becslésével kapcsolatban. Ezzel a kérdéssel az alábbiakban azonban csak érintőlegesen foglalkozunk majd; nem ez a tanulmány fő kérdése.

Mi itt a mentális zavaroknak abból a fő jellegzetességéból indulunk ki, hogy az, akinek valamilyen zavara van, másképp érez és másképpen viselkedik, mint azok, akiknek nincs, és ez a tulajdonságuk tartós. Két egyszerủ példával élve: a fent röviden bemutatott időszakosrobbanékonyság-zavar agresszív dühkitöréssekkel jár együtt, amelyeket kiprovokálhat akár egy ártatlan megjegyzés is, amelyet mások még provokációnak sem fognának fel, nemhogy erőszakkal reagáljanak rá. Ugyanakkor az antiszociális személyiségzavar egyik tünete az erősen csökkent empátia, ami olyan kegyetlen tettek elkövetésére teszik képessé őket, amelytől a zavart nem mutató ember visszariadna.

E tanulmányban azt a kérdést tesszük fel, hogy a mentális zavarok érzelmi, viselkedési és tudati sajátosságai felhasználhatók-e segédtudományként az elkövetők fellelésében, és a velük való adekvát bánásmód kialakításában?

David Freedman - David Hemenway: Precursors of lethal violence: a death row sample. Social Sciences and Medicine, 50. (2000), 12. 1757-1770.

$9 \quad$ Seena Fazel et alii: Depression and violence: a Swedish population study. The Lancet Psychiatry, 2. (2015), 3. $224-232$. 


\section{Milyen gyakran találkozhat rendör mentális zavarokkal?}

A tanulmány fent megfogalmazott célkitűzése csak akkor számíthat érdeklődésre, ha ezen alfejezet címében szereplő kérdésre adott válasz minimum „gyakran”, tehát először azt kell megvizsgálnunk, hogy milyen gyakoriak a mentális zavarok a bủnelkövetőknél.

A kérdésre adandó válasz pontossága - és a mentális zavarok gyakorisága - attól függ, hogy milyen jellegủ tanulmányokat veszünk alapul. Vannak szerzők, akik a kórtörténeti előzményekre hagyatkoznak, és a mentális zavarok gyakoriságát búnözőknél valahol 20-30\% körülinek találják. E megközelítés hátulütője, hogy a bűnözők ritkán járnak pszichiáterhez, így kórtörténetük meglehetősen hiányos. Ezzel együtt, már ez a relatíve alacsony szám is kielégíti a "gyakori” fogalmát. Ha ez a valóság, öt elkövetôből egynek (esetleg négyből egynek) mentális zavara van, ami akár önmagában is indokolná, hogy a kérdéssel komolyan foglalkozzunk.

A részarány magasabb, ha a kutatók nem kórházi nyilvántartásokra hagyatkoznak, hanem diagnosztikai kérdőívek segítségével maguk állapítják meg a mentális zavarok részarányát. Ritka az átfogó tanulmány; a kutatók többnyire csak olyan zavarokat vizsgálnak, amelyeket a bủnelkövetés szempontjából fontosabbnak vagy általában véve súlyosabbnak tekintenek. Erre a tanulmánytípusra példaként egy összefoglaló tanulmányra hivatkozunk, amely 20 ezernél több, 12 különböző országban élő bűnelkövető adatait összesítette, és a depresszióra, pszichózisra és a személyiségzavarokra koncentráltt. ${ }^{10} \mathrm{~A}$ férfi elkövetốk hozzávetőleg $65 \%$-ánál volt megállapítható valamilyen személyiségzavar, amely az esetek kétharmadában antiszociális személyiségzavar volt; 10\%-uk depressziós volt, míg 4\%-uk pszichotikus. A női elítélteknél a pszichózis ugyanilyen gyakori volt, a depresszió valamivel gyakoribb, a személyiségzavarok pedig valamivel ritkábbak voltak. A fenti számokat természetesen nem lehet összeadni, mert gyakori volt a komorbiditás (két vagy több zavar együttes jelenléte), de ennek ellenére is az elítéltek kétharmadának volt valamilyen (egy vagy több) mentális zavara. Ebből az adódik, hogy azoknak a búnelkövetôknek a többsége, akikkel a rendőr munkája során kapcsolatba kerül, valamilyen mentális zavarral rendelkezik.

Végül vannak tanulmányok, amelyek szerzői - a lehetőségek keretein belül - a teljességre törekedtek, és igyekeztek felderíteni minden zavart, amely a kutatás időpontjában kimutatható volt. Erre egy fiatalkorú bünelkövetőkön végzett vizsgálatot hozunk fel példaként. ${ }^{11}$ Itt már minden elkövetőnél kimutatható volt a „viselkedészavar” (conduct disorder). Ez első hallásra eléggé ártalmatlannak tưnik - melyik gyereknek ne lenne valamiféle viselkedészavara? Valójában azonban a „viselkedészavar” az antiszociális személyiségzavar "gyermekkori formája”, amelynek tünetei nemcsak hasonlítanak az antiszociális személyiségzavar tüneteihez, hanem ez utóbbi nem is diagnosztizálható, ha nem

10 Seena Fazel - John Danesh: Serious mental disorder in 23000 prisoners: a systematic review of 62 surveys. The Lancet, 359. (2002), 9306. 545-550.

11 Andrew J. Gostisha et alii: Beyond physiological hypoarousal: The role of life stress and callous-unemotional traits in incarcerated adolescent males. Hormones and Behavior, 65. évf. (2014), 5. 469-479. 
előzte meg 15 éves kor előtt az előbbi. A két zavar együttesen egy korán jelentkező és élethosszig tartó állapotot fed le, amelyet azért választottak szét gyermekkori és felnőtt változatra, mert a személyiség gyermekkorban még nem alakult ki, így zavart sem szenvedhet. Nos, ehhez az általánosan jelentkező zavarhoz társult néhány további zavar. A vizsgálati alanyok 90\%-ának (10 viselkedészavaros gyermekből 9-nek) volt még legalább egy, de gyakran több járulékos zavara is, például figyelemhiányos hiperaktivitás zavar, drogfüggés és poszttraumásstressz-zavar, hogy a leggyakoribbakat emeljük ki. Ez a tanulmány már azt mutatja, hogy minden elkövető rendelkezik valamilyen mentális zavarral, sőt, többségük egyszerre többel is. Egyébként nem véletlenül hivatkoztunk erre a tanulmányra, hiszen saját kutatásunkban, amelyet e tanulmány vége felé mutatunk be, szintén fiatalkorú bünelkövetőket vizsgáltunk.

Mindezt azért mutattuk be ilyen részletesen, mert a szakirodalomban különböző számok keringenek, és ez félrevezetheti azokat, akik nem ismerik e számok hátterében meghúzódó kutatói technikákat. A különböző tanulmányok számai természetesen akkor sem egyeznek meg teljesen, ha olyanokat hasonlítunk össze, amelyek hasonló kutatói megközelítést alkalmaztak. Anélkül azonban, hogy számháborúba keverednénk, biztonsággal megállapíthatjuk, hogy a bủnelkövetők az elsöprő többségének, akikkel egy rendőr kapcsolatba kerül, mentális zavara van. A részarány lehet 70-80-90-100\%; egy dolog azonban bizonyos: a mentálisan nem zavart elkövetők elenyésző kisebbségben vannak.

Ha ezt a rendészettudomány nem veszi figyelembe, megfosztja magát egy fontos, gyakorlatban alkalmazható ismeretegyüttestől.

\section{Pszichiátriai ismeretek rendészettudományi alkalmazásai}

Egyetlen tanulmányban lehetetlen kimerítően áttekinteni azokat a területeket, ahol a pszichiátriai ismeretek segítségére lehetnek a rendészet tudományának. Ennek akárcsak felületes áttekintésére is minimum egy cikksorozatra lenne szükség, de még inkább egy szakkönyvre. Az alábbiakban végigkövetjük egy nyomozás és az azt követő események lépéseit a helyszíni szemlétől a szabadlábra helyezésig, és megvizsgáljuk, hogy melyik lépésnél milyen segítséget nyújthat a pszichiátria. Helyszúke miatt csak példákra tudunk hagyatkozni, és még a példákat is erősen szelektálnunk kellett, hogy ne lépjünk túl a kereteken. Mint látni fogják, a kriminálpszichiátria egyes alterületei nagyon különböző fejlődési szakaszban vannak, de megítélésünk szerint még ott is érdemes figyelni eredményeire, ahol azok jelenleg inkább az ígéret, mint a megvalósítás fázisában vannak.

Megjegyezzük, hogy az igazságügyi pszichiátriát szándékosan hagytuk ki a fejezetből, mert egy bíróság számára diagnózisokat felállítani speciális szakértelmet igényel, amellyel egy rendőr - hacsak nincs szakirányú végzettsége és tekintélyes tapasztalata - nem rendelkezhet. Azokon a területeken azonban, amelyet kiválasztottunk, nincs 
feltétlenül szükség pszichiátriai szakvizsgára, a leírt alkalmazási módok szempontjából legalábbis nincs. Erre a kérdésre a következő fejezetben térünk vissza.

\section{Helyszín megtekintése}

Van olyan nyomozásban tapasztalt szerző, aki a pszichiáterek bevonását már a helyszín megtekintésével kezdené, ${ }^{12}$ mivel a nyomozati anyagból (vagyis utólag), sok olyan részlet rejtve maradhat, amely pszichiátriai szempontból lényeges. Ennek igazolására a tanulmány sok konkrét esetet ír le, amelyek közül egyet idézünk fel röviden. Az elkövető elbarikádozta magát a helyszínen, tűzpárbajt kezdeményezett, és megölt egy rendőrt. A védelem az elkövető diagnosztizált mentális zavarára épített, de a helyszínt a megfelelő pillanatban megtekintette egy pszichiáter, aki megállapította, hogy (1) az elkövető nehezen beszerezhető korszerű fegyverekkel jelent meg az elkövetés helyszínén, (2) az elbarikádozás módja kiváló stratégiai érzékről tanúskodott, (3) a rejtekhelyet tudatosan és ügyesen használta ki, és végül (4) a napnak az adott órájában az ajtón belépő rendőr árnyékát látnia kellett, és egy figyelmeztetéssel is távol tarthatta volna, vagyis nem kellett volna megölnie. Bár a mentális zavar nem volt kétséges, az események azt igazolták, hogy az elkövető tudatában volt cselekedeteinek, jól átlátta a helyzetet, és mások kárára tudatosan cselekedett - tehát felelős volt tetteiért. A tanulmányban felsorolt példák mindegyike azt volt hivatott igazolni, hogy a helyszíni szemle segíti a pszichiátert abban, hogy helyes ítéletet alkosson az elkövető beszámíthatóságáról.

\section{Bûnözöi profilalkotás}

A nyomozás - nem kötelező, de adott esetben hasznos - következő lépése a bűnözői profilalkotás: az az eljárás, amelynek során egy szakember összegezi az elkövetőnek annyi sajátosságát amennyi csak lehetséges, anélkül, hogy az elkövetőt ismerné. A munkát a nyomozás során felszínre kerülő ismeretek alapján végzik el, és két dologra használják: az elkövetői kör szúkítésére, amivel jelentős mennyiségű munka takarítható meg, és gyorsítható a nyomozás, illetve az azonos elkövetőnek tulajdonítható (sorozat-)bűncselekmények azonosítására, amivel egyrészt szintén gyorsítható a nyomozás, mert a különböző bűncselekmények információi összegezhetők, másrészt javul a felderített bűncselekmények aránya. A bűnözői profilalkotásnak sok módszere van az egyszerú statisztikai eljárásoktól a komoly matematikai apparátust felvonultató technikákig; a klinikai, pontosabban pszichiátriai profilozás a legújabb megközelítések egyike. Alapja, hogy egy mentálisan érintett személy viselkedése sajátos, ami alapján felismerhető az állapota, ez pedig támpont lehet a nyomozás során. Más profilozási

12 Kris Mohandie - J. Reed Meloy: The value of crime scene and site visitation by forensic psychologists and psychiatrists. Journal of Forensic Sciences, 58. (2013), 3. 719-723. 
eljárások sokkal kiforrottabbak; a klinikai profilozás egyelőre az alapfeltevések megfogalmazásánál és a kezdeti megfigyelések fázisánál tart.

Megfigyelték például, hogy a pszichotikus gyilkosok többnyire fiatal férfiak voltak, többségüknek bűnözői előélete volt, erős felindulás hatására támadtak ismerőseikre vagy - különösebb válogatás nélkül - családtagjaikra. ${ }^{13}$ Ezzel szemben a depreszszióban szenvedő gyilkosok többnyire a harmincas éveikben járó nők voltak, akiknek családja volt, a gyilkosságot előre eltervezték, célpontjaik pedig saját gyermekeik, illetve élettársuk volt. A gyilkosság elkövetése után gyakran lettek öngyilkosok. Egy másik tanulmány ${ }^{14}$ úgy találta, hogy a pszichotikus elkövetők többnyire valamilyen éles tárgy segítségével gyilkoltak, míg a depressziósok többnyire megfojtották áldozatukat. A kétféle mentális zavar tehát - statisztikailag legalábbis - elkülönítette egymástól az elkövetőket, a bűntett kiváltó okát, módját és eszközét, részben még az áldozatokat is.

Ezek és a hasonló tanulmányok, amelyekből elég sok van, természetesen csak információmorzsákat szolgáltatnak; egy használható klinikai profilozási rendszer kidolgozásáig még hosszú az út. Úgy tűnik azonban, hogy a pszichiátria olyan információkat tud szolgáltatni, amelyeket más profilozási eljárások nem, ezért könnyen lehetséges, hogy a megközelítésnek, mihelyt sikerül túllépnie a kezdeti nehézségeken, szerepe lesz a profilalkotásban.

\section{Az elkövetö elfogása}

A pszichiátriai megközelítésnek az elkövetők elfogása során is szerepe lehet, sőt, bizonyos esetekben kell is szerepe legyen. Két példát hozunk fel ennek igazolására. Könnyen előfordulhat, hogy az elfogás pillanatában az elkövető drog hatása alatt áll. Megjegyezzük, hogy a drog intoxikáció önmagában mentális zavar, és szerepel a fent említett két kézikönyvben, drogonkénti bontásban. Az elkövető viselkedéséből és különböző testi jeleiből viszonylag könnyen megállapítható, hogy milyen típusú drogot fogyasztott, ami két szempontból fontos. Először is: az erős intoxikáció két nagy drogcsalád, a nyugtató hatású drogok (például ópium, heroin), illetve az élénkítőszerek (például amfetamin, kokain) esetében életveszélyes állapot, de a veszély és az ebből fakadó tennivalók drogspecifikusak. Az élénkítőszerek (pszichostimulánsok) hatására a test túlmelegedhet és a vérnyomás fokozódhat, ami annyira megterhelheti a szívet, hogy az leáll. Ezt nevezik „hirtelen” vagy „diszkó” halálnak. Egy ilyen kritikus helyzetben az elkövetőnek vizet kell adni, és hideg helyre kell vinni, ami megmentheti életét addig, amíg a mentők megérkeznek. Az ópium- vagy heroin-túladagolás hatására ezzel szemben a test kihúl és a légzés leáll. Ilyenkor az illető melegen tartása és a mesterséges léle-

13 S Richard-Devantoy et alii: Homicide et psychose: particularités criminologiques des schizophrènes, des paranoïaques et des mélancoliques. L'Encéphale, 34. (2008), 4. 322-329.

14 Valeria Abreu Minero - Edward Barker - Rachael Bedford: Method of homicide and severe mental illness: A systematic review. Aggressive and Violent Behavior, 37. (2017), 11. 52-62. 
geztetés a megoldás. Fontos tudni ugyanakkor, hogy a droghatás fokozatosan alakul ki, és az, aki az elfogás pillanatában még csak enyhén intoxikált, egy óra múlva már életét is vesztheti a fenti élettani hatások miatt. Ezért drogintoxikáció esetén - föleg ha nem lehet tudni, hogy mikor és milyen mennyiségben történt a drogfogyasztás - a gyanúsítottat fél-egyóránként ellenőrizni kell, hogy nem súlyosbodott-e az állapota, és ha ez bekövetkezett, úgy kell eljárni, mint fent leírtuk. Megjegyezzük, hogy teljesen más a helyes eljárás hallucinogének esetén, de erre helyszúke miatt nem térhetünk ki. Végül a második példánk az antiszociális személyiségzavarra vonatkozik; a pszichiátriai részletek mellőzésével kijelenthető, hogy ezek az emberek a legkisebb lehetőséget is meg fogják ragadni a menekülésre, mert nagyon bíznak saját képességeikben, és vakmerők, ugyanakkor semmitől nem riadnak vissza, mert érzéketlenek mások szenvedése iránt. Ezért ilyen elkövetővel szemben csak jelentős túlerővel és rendkívül szervezetten lehet fellépni.

Ezek nyilván csak szemelvények a rendelkezésre álló ismeretanyagból, de egyértelmúen mutatják, hogy ha a rendőr helyesen méri fel az elkövető állapotát, és tudatában van a helyes stratégiának, életeket menthet - az elkövetőét vagy esetleg a sajátját.

\section{Kihallgatás}

A kihallgatás-lélektan túlságosan bonyolult ahhoz, hogy részleteiben elmerüljünk, ezért csak jelzésszerűen említjük meg, hogy:

Aki marihuánát fogyasztott, képtelen odafigyelni kérdésekre, és nem tudja összeszedni gondolatait a válaszhoz, bár esetleg élénknek és jókedvűnek mutatkozik.

a) Aki pszichostimuláns hatása alatt áll, ingerlékeny és minimális provokáció (például egy élesen feltett kérdés) hatására is agresszivvé válhat.

b) A depressziós mindenért magát hibáztatja, és eleve sötéten látja saját jövőjét, ezért könnyen beismerhet el nem követett bűntetteket, ha nyomást gyakorolnak rá.

c) Aki krónikus drogbetegségben (addikcióban) szenved, azért vallhat könnyen és esetleg hamisan, mert hiányzik neki a drog, és már nagyon várja, hogy újra kijusson az utcára, ahol megszerezheti. Megjegyzendő, hogy a drogaddikciónak mint mentális zavarnak ugyanúgy könnyen felismerhető jelei vannak, mint az akut drogintoxikációnak.

d) Az antiszociális személyiségzavaros tehetségesen hazudik, és könnyedén becsaphatja a poligráfot („hazugságvizsgáló gépet”), mert élettani stresszválaszai minimálisak.

e) A bordeline személyiségzavaros ember könnyen meggyúlölheti, de akár istenítheti is kihallgatóját, sőt, menet közben könnyen átválthat egyik állapotból a másikba, ami a kihallgatás során sok zavart okozhat, és megfelelő tapintatot igényel; stb. 
Ezek természetesen csak szemelvények; a lényeg, hogy a kihallgatott pszichiátriai állapota adott esetben speciális kihallgatási stratégiát igényel, amelyet csak az alkalmazhat, aki az állapotot felismeri, és tudja, hogy mit kell tennie.

\section{Más rendészeti helyzetek}

A pszichiátriai ismereteknek szerepe van más helyzetekben is, például a büntetés-végrehajtásban. Talán Megargee volt az első, aki személyiségjegyeik és pszichiátriai állapotuk alapján csoportosította az elkövetôket, és leírta, hogy az így azonosított bűnözőkkel miképpen tanácsos bánni a börtönben. ${ }^{15} \mathrm{Az}$ általa azonosított tíz csoportból a legenyhébb állapotban lévők (ezeket az „Item” fantázianévre keresztelte) nem okoznak problémát a börtönben, míg a legsúlyosabb állapotban lévők esetében (például azoknál, akiket ő a Delta, Foxtrot és How nevekkel illetett) a társaktól való elkülönítést, szigorú felügyeletet és pszichiátriai kezelést javasolt. Korai eredményeit később többen megerősítették. ${ }^{16}$

Végezetül a próbaidőre bocsátásnál, de más esetekben is fontos lehet a bünismétlés veszélyének felmérése, ami pszichiátriai információk hiányában sokszor nehéz. Ezt számtalan adat bizonyítja; itt csak egy olyan érdekes életkori sajátosságra térünk ki, ami nem magától értetődő: felnőtteknél a bűnismétlés legnagyobb veszélye - egymástól függetlenül - az antiszociális személyiségzavar és a drogaddikció, ${ }^{17}$ ezzel szemben fiatalkorúaknál a mentális zavaroknak nincs köze a bünismétléshez, kivéve, ha drogaddikcióhoz társulnak. ${ }^{18}$

$\mathrm{Ez}$ a rövidke alfejezet természetesen nem áttekintette az ismereteket - mint ahogy a fejezet többi része sem. Pusztán arra szolgált, hogy rávilágítson: a pszichiátriai ismeretek csaknem minden tevékenységi területen segítséget nyújtanak a rendőr számára.

\section{Pszichiátriai ismeretek a rendör gyakorlatában}

A fentiek valószínúleg meggyőzték az olvasót arról, hogy a pszichiátria segítségére lehet a rendőrségnek, annál is inkább, mert a testület elég gyakran veszi igénybe pszichiáterek segítségét, tehát tudatában van annak, hogy az együttmúködés hasznos. Itt

15 Edwin I. Megargee: A New Classification System for Criminal Offenders. Criminal Justice and Behavior, 4. (1984), 9. 107-216.; Edwin I. Megargee - Martin J. Bohn Jr.: A New Classification System for Criminal Offenders, IV: Empirically Determined Characteristics of the Ten Types. Correctional Psychologist, 4. (1977), 6. 149-210.

16 Michèle Sneyers et alii: Using the Megargee System Among Belgian Prisoners: Cross-Cultural Prevalence of the MMPI2 Based Types. Psychological Reports, 100. (2007), 3. 746-754.; Mally Shechory - Joshua M. Weiss - Rachel Weinstain: Differentiating Offenders by Index Offense and Personality Inventories: The Characteristics of Adult Probationers in Israel. International Journal of Offender Therapy and Comparative Criminology, 57. (2013), 3. 312-331.

17 Martin Grann - John Danesh - Seena Fazel: The association between psychiatric diagnosis and violent re-offending in adult offenders in the community. BMC Psychiatry, 25. (2008), 8. 92-99.

18 Oliviere Colins et alii: Psychiatric Disorder in Detained Male Adolescents as Risk Factor for Serious Recidivism. Canadian Journal of Psychiatry, 56. (2011), 1. 44-50. 
azonban nem arról szeretnénk meggyőzni az olvasót (rendészeti szakembert), hogy a pszichiátriai ismereteknek helye van a rendészetben, hanem arról, hogy ilyen ismeretekkel a rendőröknek maguknak is rendelkezniük kell - nem pusztán azért, hogy szakmai múveltségük keretei táguljanak, hanem azért, hogy ezeket az ismereteket felhasználják a gyakorlatban.

Ez természetesen nem azt jelenti, hogy a rendészeti hallgatókat saját szakmájuk elsajátítása mellett pszichiáterré is ki kell képezni. Az egyetemi rendészeti tanulmányok nem helyettesíthetik azt a nagyjából 10 éves képzést, amely valakiből pszichiátert farag. A két véglet - „fogalma sincs a pszichiátriáról” és „professzionális pszichiáter” - között azonban számtalan átmenet van, és nem szerencsés, ha a rendôr az előzőhöz áll közelebb. Fent már igazoltuk: a bűntettek elkövetőinek elsöprő többségénél jelen van valamilyen mentális zavar. Nem értheti meg őket, és nem kezelheti őket megfelelően az, akinek fogalma sincs a pszichiátriáról.

Analógiaként a jogi képzést hozzuk fel példának. A Rendészettudományi Kar nem bírókat, ügyészeket és ügyvédeket képez; ennek ellenére, a jogismeret igen hangsúlyos része a képzésnek, és a rendőr hamar bajba kerülhet, ha elfelejti azt, amit az egyetemen tanult. Nem azért részesül jogi képzésben, hogy az igazságügyben helyezkedjen el, hanem azért, hogy jól végezze a munkáját. Ugyanez a pszichiátriáról is elmondható. A rendôr hallgatónak nem azért kell megismernie a mentális zavarokat, hogy diagnózist állítson fel és gyógyítson. Azért van szüksége pszichiátriai ismeretekre, hogy jobban végezze a munkáját.

A rendőrnek nem kell minden pszichiátriai kórképet ismernie; elég, ha ismeri azokat, amelyek a leggyakrabban fordulnak elő a búnelkövetők között. Nem kell határeseteket elkülönítenie, összetett vagy ritka kórképeket felismernie, nem kell kezelést előírnia, vagy a javulás és romlás jeleit felismernie. Néhány egyszerú tünet alapján azonosítania kell meglehetősen kis számú zavart, és az azonosítás után eldöntenie, hogy hogyan jár el a gyanúsított és saját érdekében, mindvégig szem előtt tartva a fő célt, a bűntettek kezelését.

A cél a szerző tapasztalatai alapján elérhető. Eddig két évfolyam vizsgázott kriminálpszichiátria tárgyból a rendészettudományi karon; összesen mintegy 150 hallgatónak kellett olyan magyarországi büntetteket elemeznie, amelyeket azok írtak le, akik a nyomozásban részt vettek. A mentális zavar helyes azonosítása csaknem 100\%-os volt, és ugyanilyen jó arányban mérték fel a hallgatók azt, hogy az adott bünelkövetővel szemben mi a helyes rendészeti stratégia. A részletekben, például a motivációk azonosításában már nem volt ilyen kedvező a helyzet, de a 70\% körüli sikerarányt itt is elérték. Mivel a kriminálpszichiátria oktatásának nincs túl régi hagyománya idehaza - és külföldön sincs - még nem lehet felmérni, hogy hosszú távon megtérül-e a tárgy oktatásába és elsajátításába fektetett energia. Úgy túnik azonban, hogy azok, akik bünesetek kapcsán sajátították el az alapvető pszichiátriai ismereteket, képesek más büntettek esetében felismerni a rendészetileg legfontosabb zavarokat, és kiválasztani a legcélravezetôbb intézkedési módokat. 
Természetesen felvethető a kérdés, hogy miért ne hagyatkozhatna a rendőrség kizárólag a pszichiáterekre? A kihallgatások esetében például az a szabály, hogy a mentálisan érintett bűnelkövetők esetében az eljárást pszichológus vagy pszichiáter támogatja. Ez nagyon helyes, ha a kórkép bonyolult vagy súlyos. Mint láttuk azonban - és ezt saját kutatásunk is bizonyítja alább - a bűnözők elsöprő többségének van valamilyen mentális zavara. Ezek szerint csaknem minden kihallgatásnál pszichológus vagy pszichiáter segítségére lenne szükség, ami technikailag aligha megoldható. Még fontosabb azonban, hogy a bünügyek kapcsán számos intézkedést kell foganatosítani, ami dilemma elé állít bennünket: vagy a pszichiátert kell kiképezni rendészeti munkára, vagy a rendőrt kell alapvető pszichiátriai ismeretekkel ellátni. Mivel a bünügyek kezelése rendészeti és nem pszichiátriai feladat, a második megoldás kézenfekvő. Mint fent jeleztük azonban, a rendőr soha nem lesz pszichiáter (hacsak el nem végzi az orvostudományi egyetemet, és le nem teszi a pszichiátriai szakvizsgát), így pszichiáterek segítségére akkor is szükség lesz, ha már minden rendőr rendelkezik azokkal az alapvető ismeretekkel, amelyekről fent beszéltünk. Ezek az ismeretek - ismételjük - nem arra szolgálnak, hogy kiváltsák a pszichiáterek szakértelmét, hanem hogy hatékonyabbá tegyék a rendőri munkát.

\section{Mentális zavarok fiatalkorú bünelkövetők körében - saját kutatás}

E tanulmány szerzői egy olyan kutatásnak állnak körülbelül a feleútján, amelynek végső céljai között szerepel annak felmérése, hogy milyen gyakoriak a mentális zavarok a fiatalkorú bűnelkövetők körében, és hogy az egyes zavarok milyen jellegű bűntettekkel asszociálódnak. További cél annak felmérése, hogy a mentális zavar, más pszichológiai sajátosságok és a bűnözői előélet alapján mennyire lehet megjósolni az elkövetők zárt intézményben várható viselkedését. A kutatás részben rokonságot mutat Megargee és követőinek fent bemutatott munkásságával. Az eredményeket nem mutatjuk be részletekbe menően; csak azokra térünk ki, amelyek e tanulmány szempontjából érdekesek. Bár a mintaszám kevesebb mint fele a tervezettnek, már most nagyon releváns eredményekről számolhatunk be.

\section{A kutatás résztvevôi}

A kutatást egy budapesti intézetben végeztük, ahol a bíróságok által letartóztatásba helyezett fiatalkorú fiúk számára biztosítanak javítóintézeti ellátást. A kutatásban való részvétel önkéntes és anonim volt. A részvételbe való beleegyezésre tájékoztatás után került sor; a beleegyezés visszavonható volt a vizsgálat bármely pontján. A résztvevőket a kutatás adatbázisában kódokkal azonosítottuk (javítóintézet kódja és sorszám); személyneveket nem rögzítettünk. A kutatás anyagaiba kizárólag a kutatást végző személyek nyerhettek betekintést. 
A kutatás részvevőinek életkora 14 és 17 év között volt, átlagéletkoruk 16,2 év volt. Elkövetett bűntetteik megoszlása a következő volt: rablás (kerekítve 51\%), emberölés (12\%), lopás (12\%), kifosztás (6\%), szexuális erőszak (6\%), súlyos testi sértés (6\%), kábítószer-kereskedelem (4\%), csalás (2\%), önbíráskodás (2\%).

\section{Módszerek}

Adatfelvételre két alkalommal került sor; először a pszichiátriai, majd a szociológiai és pszichológiai adatokat vettük fel. Az alkalmazott módszerek közül főleg a pszichiátriai vizsgálat releváns e tanulmány szempontjából, ezért azt ismertetjük részletesen. A teljesség kedvéért megemlítjük az adatfelvétel során alkalmazott többi módszert is.

\section{Pszichiátriai vizsgálat}

A vizsgálat a javítóintézet területén egy csendes, nyugodt vizsgálati helyiségben történt, a vizsgálati személyen és a vizsgálón kívül más nem volt jelen. A mentális állapotot az International Neuropsychiatric Interview for Children and Adolescents (M.I.N.I. Kid 7.0.2) ${ }^{19}$ segítségével mértük fel; ezt Balázs és munkatársai ${ }^{20}$ adaptálták a magyar populációra. A kérdőív az Amerikai Pszichiátriai Társaság által 2013-ban megjelentetett, a pszichiátriai betegségeket rendszerező Diagnostic and Statistical Manual of Mental Disorders kritériumrendszerére támaszkodik. A kérdőív zárt kérdéseket tartalmaz, amelyekre igen-nem válaszokat kell adni; minden kérdés egy pszichiátriai betegségre jellemző tünetet tár fel. A pszichiátriai eszköz használata a kérdések szó szerinti felolvasását követeli meg, de a helyes alkalmazáshoz elengedhetetlen időnként a szövegtől való eltérés, a kérdésekre adott válaszok alapos körüljárása annak tisztázása céljából, hogy valódi tünet került a felszínre, és nem a kérdést értette félre a vizsgálati alany. Erre a M.I.N.I. Kid szerzője külön ajánlást tesz a használati útmutatóban. Másik fontos jellemzője a kérdőívnek, hogy speciális szaktudást igényel a felvétele, kizárólag pszichiáter vagy pszichiátriában jártas szakember alkalmazhatja. A félig strukturált interjú jelentősége az, hogy az egyébként igen szubjektív, nehezen ellenőrizhető pszichiátriai vizsgálathoz a lehetőségekhez képest objektív mérőeszközül szolgál. Ennek tudományos kutatások esetében van különösen nagy jelentősége, hiszen amikor egy nagyobb mintán akarjuk a pszichés jelenségeket felmérni és összehasonlítani, igen fontos szempont, hogy a lehető legpontosabb módszerrel, valóban ugyanazokat a tüneteket rögzítsük, illetve zárjuk ki, és a vizsgálati alanyok közötti valódi különbségeket és hasonlóságokat jelezzék az adatok. A kérdőívcsomag 25 pszichiátriai kórképen keresztül tárja fel a mentális állapotot. Egy interjú nagyjából 60 percet vett igénybe, a vizsgálat a vizsgálati alany informált beleegyezésével történt, amelyről írásban nyilatkozott.

19 David V. Sheehan et alii: Reliability and Validity of the Mini International Neuropsychiatric Interview for Children and Adolescents (MINI-KID). Journal of Clinical Psychiatry, 71. (2010), 3. 313-326.

20 Balázs Judit et alii: A Gyermek M.I.N.I. kérdőív magyar nyelvű változatának ismertetése. Psychiatria Hungarica, 19. (2004), 4. 358-364. 


\section{Szociológiai és pszichológiai vizsgálat}

A szociodemográfiai, kriminológiai, kriminalisztikai, oktatási, gyermekvédelmi és intézményi életre vonatkozó információkat aktakutatás módszerével rögzítettük. Fontos megjegyezni, hogy a kutatási adatbázisba ezek az adatok a résztvevő kódja alatt és nem személynevéhez kapcsoltan jelentek meg. Megismerhettük a vizsgálati alanyok családi hátterét, életkörülményeit, életútját, iskolai pályáját, pedagógiai véleményeket, környezettanulmányokat, a bűncselekménnyel kapcsolatos iratokat, javítóintézeti véleményt.

A pszichológiai sajátosságok megragadásához az elkövetők agresszióhoz, stresszhez, élménykereséshez és érzelemfelismeréshez kapcsolódó attitűdjeit mértük fel, olyan tesztekkel, mint a Buss-Perry Agresszió, Raine-féle Reaktív-Proaktív Agresszió, Észlelt stressz, Gyermekkori trauma, Szenzoros élménykeresési kérdőívek, és az Arckifejezés és érzelemfelismerés teszt.

\section{Szelektált eredmények}

A leggyakoribb mentális zavar a mintában a viselkedészavar volt; ezt azonosítani lehetett a mintának csaknem felében (1. táblázat bal oldali oszlopok). Ezt követte gyakoriságban öt olyan zavar, amely az elkövetőknek legalább negyedénél jelen volt. Nyilvánvaló, hogy már ennek a hat zavarnak az összege is felülmúlja a 100\%-ot, ami a komorbiditásnak köszönhető: annak, hogy ugyanannál az elkövetőnél egyszerre több mentális zavar volt jelen. Egy átlagos elkövető 4-9 mentális zavartól szenvedett egyszerre (1. táblázat, jobb oldali oszlopok); ebbe a kategóriába esett az elkövetőknek csaknem kétharmada. Mindössze két elkövető (a minta 4,1\%-a) volt mentes a mentális zavaroktól.

1. táblázat: A leggyakoribb mentális zavarok, és komorbiditás fiatalkorú bünelkövetók körében. Forrás: a szerző́k saját kutatási eredményei

\begin{tabular}{|l|c|c|c|}
\hline \multicolumn{1}{|c|}{ Zavar neve } & $\begin{array}{c}\text { Zavar aránya } \\
\text { elkövetök körében } \\
(\mathbf{\%})\end{array}$ & $\begin{array}{c}\text { Zavarok száma } \\
\text { elkövetónként } \\
\text { (\%) }\end{array}$ & $\begin{array}{c}\text { Elkövetök aránya } \\
\text { zavarszám szerint } \\
\text { (\%) }\end{array}$ \\
\hline Viselkedészavar & 40 & 0 & 4,1 \\
\hline Droghasználati zavar & 34 & $1-5$ & 18,4 \\
\hline Major depresszió & 29 & $4-6$ & 28,6 \\
\hline Oppozíciós zavar & 29 & $7-9$ & 34,7 \\
\hline $\begin{array}{l}\text { Figyelemhiányos } \\
\text { hiperaktivitás zavar }\end{array}$ & 27 & $10-12$ & 10,2 \\
\hline Bipoláris zavar & 26 & $12-n e ́ l$ több & 4,1 \\
\hline
\end{tabular}


A tervezett további elemzések közül mindössze kettôt mutatunk be nagyon röviden. A zavarok száma - talán a kis mintaszám miatt - nem volt összefüggésben az elkövetett büntettek súlyával; az emberölések, rablások és lopások elkövetőinek körében a komorbid mentális zavarok száma egyaránt 6 körül volt. Ugyanakkor az emberölés és súlyos testi sértés elkövetőinél a vezető (leggyakoribb) pszichiátriai kórkép a viselkedészavar volt, a kábítószer-kereskedőknél a drogaddikció, míg a szexuális búncselekmények elkövetőinél a major depresszió. A mentális zavar összefüggést mutatott az intézeti élettel is; a legtöbb dicséretet a szorongásban szenvedők kapták, a legtöbb fegyelmit pedig az alkalmazkodási zavarban szenvedők - kivéve, ha erőszakos cselekedetekért járt a fegyelmi, mert akkor az alkoholhasználati zavarban szenvedők átvették a vezetést.

\section{Következtetések}

A kutatás e kezdeti fázisában a felismert összefüggések megerősítésre várnak. Azonban a mentálisan érintett elkövetők igen magas, 96\%-os arányát a további kutatás aligha csökkenti majd lényegesen, és az igen magas komorbiditás is eléggé szilárd alapokon nyugvónak tűnik. A kórképek és a bűntípusok közötti összefüggés már kevésbé látszik biztosnak a kis mintaszám miatt, és az sem bizonyos, hogy az intézeti élet és a mentális zavarok közötti összefüggést a további kutatások megerősítik, bár az összefüggés logikus, és összhangban van a zavarok általánosan ismert jellegzetességeivel.

\section{Zárszó - mentális zavar, büntetőjogi felelősség és rendészeti intézkedés}

Saját kutatásunk - amellett, hogy új, korábban még fel nem tárt összefüggések felderítését ígéri - igazolja azt, amit irodalmi források alapján az 1.3. alfejezetben írtunk. A fiatalkorú elkövetóknél a pszichiátriai esetek az elsöprő többséget alkotják, sőt, az elkövetôk többszörösen zavartak. Ez igazolja azt, hogy a rendőröknek pszichiátriai ismeretekkel kell rendelkezniük, de egyúttal felvet egy kérdést. Felelős-e tetteiért egy mentálisan többszörösen zavart elkövető?

A válasz nyilván bonyolult, és függ a válaszadó beállítottságától. Nincs helyünk arra, hogy részletesen elemezzük a helyzetet, de elkülönítjük azokat a fő tudatállapot-típusokat, amelyek megléte csak egy árnyalt választ tesz lehetôvé. Az értelmileg akadályozottak nem látják át tetteik következményeit, és nem mindig látják át a jó (törvényes) és rossz (törvénytelen) közötti különbséget. Ez nyilván csökkenti vagy az akadályoztatás mértékétől függően akár meg is szünteti felelősségüket. A kóros tudatállapot azokra jellemző, akik értelmileg nem akadályozottak, ugyanakkor hosszabb-rövidebb időre elvesztik mérlegelési képességüket. Ebbe a kategóriába tartoznak például azok, akik a tett elkövetésekor pszichotikus állapotban voltak, és a büntettet ennek hatására követték el. 
A felelősség kérdése nyilván náluk is igen hangsúlyosan vetődik fel. Az értelmileg akadályozottak a mintánkban nem voltak jelen, a pszichotikusok pedig nagyon kevesen voltak. A többi zavar sem értelmi akadályoztatással, sem kóros elmeállapottal nem jár együtt; az ilyen zavarokban szenvedőknél a zavar pusztán kockázati, nem „kényszerítő" tényező.

Zárszóként azonban meg kell jegyeznünk, hogy a rendőrök felvértezése pszichiátriai ismeretekkel nem függ az elkövetők büntetőjogi felelősségétől. A rendőröknek akkor is helyesen kell eljárniuk, ha az elkövető felelős tetteiért, és akkor is, ha nem.

\section{FELHASZNÁLT IRODALOM}

Balázs Judit - Bíró Andrea - Dálnoki Dominika - Lefkovics Eszter - Tamás Zsuzsa - Nagy P. - Gádoros J.: A Gyermek M.I.N.I. kérdőív magyar nyelvű változatának ismertetése. Psychiatria Hungarica, 19. (2004), 4. 358-364.

Brussel, James A.: Casebook of a crime psychiatrist. New York, Bernard Geis Associates, 1968.

Colins, Oliviere - Robert Vermeiren - Pauline Vahl-Monica Markus - Eric Broekaert - Theo Doreleijers: Psychiatric disorder in detained male adolescents as risk factor for Serious Recidivism. Canadian Journal of Psychiatry, 56. (2011), 1. 44-50. DOI: https://doi.org/10.1177/070674371105600108

DSM-5, Diagnostic and Statistical Manual of Mental Disorders, Fifth Edition. Arlington, VA, American Psychiatric Association, 2013. DOI: https://doi.org/10.1176/appi.books.9780890425596

Fazel, Seena - John Danesh: Serious mental disorder in 23000 prisoners: a systematic review of 62 surveys. The Lancet, 359. (2002), 9306. 545-550. DOI: https://doi.org/10.1016/s01406736(02)07740-1

Fazel, Seena - Achim Wolf - Zheng Chang - Henrik Larsson - Guy M. Goodwin - Paul Lichtenstein: Depression and violence: a Swedish population study. The Lancet Psychiatry, 2. (2015), 3. 224-232. DOI: https://doi.org/10.1016/s2215-0366(14)00128-x

Freedman, David - David Hemenway: Precursors of lethal violence: a death row sample. Social Sciences and Medicine, 50. (2000), 12. 1757-1770. DOI: https://doi.org/10.1016/s0277-9536(99)00417-7

Gostisha, Andrew J. - Michael J. Vitacco - Andrew R. Dismukes - Chelsea Brieman - Jenna Merz - Elizabeth A. Shirtcliff: Beyond physiological hypoarousal: The role of life stress and callous-unemotional traits in incarcerated adolescent males. Hormones and Behavior, 65. (2014), 5. 469-479. DOI: https://doi.org/10.1016/j.yhbeh.2014.03.016

Grann, Martin - John Danesh - Seena Fazel: The association between psychiatric diagnosis and violent re-offending in adult offenders in the community. BMC Psychiatry, 25. (2008), 8. 92-99. DOI: https://doi.org/10.1186/1471-244X-8-92

ICD-10 The ICD-10 Classification of Mental and Behavioral Disorders. Geneva, World Health Organization, 1999.

McDermott, Barbara E. - Cameron D. Quanbeck - David Busse - Kalynn Yastro - Charles L. Scott: The accuracy of risk assessment instruments in the prediction of impulsive versus predatory aggression. Behavioral Sciences and the Law, 26. (2008), 6. 759-777. DOI: https://doi.org/10.1002/bsl.842

Megargee, Edwin I. - Martin J. Bohn Jr.: A New Classification System for Criminal Offenders, IV: Empirically determined characteristics of the ten types. Correctional Psychologist, 4. (1977), 6. 149-210. DOI: https://doi.org/10.1177/009385487700400204

Megargee, Edwin I.: A New Classification System for Criminal Offenders. Criminal Justice and Behavior, 4. (1984), 9. 107-216. DOI: https://doi.org/10.1177/0093854884011003007

Minero, Valeria Abreu - Edward Barker - Rachael Bedford: Method of homicide and severe mental illness: A systematic review. Aggressive and Violent Behavior, 37. (2017), 11. 52-62. DOI: https:// doi.org/10.1016/j.avb.2017.09.007 
Mohandie, Kris - J Reed Meloy: The value of crime scene and site visitation by forensic psychologists and psychiatrists. Journal of Forensic Sciences, 58. (2013), 3. 719-723. DOI: https://doi. org/10.1111/1556-4029.12135

Philipp, M.: Psychotic aggression in the medical emergency service. Medizinische Welt, 30. (1979) 39. 1436-1438.

Richard-Devantoy, S. - A. S. Chocard - A. I. Bouyer-Richard - J. P. Duflot - J. P. Lhuillier - B. Gohier J. B. Garré: Homicide et psychose: particularités criminologiques des schizophrènes, des paranoïaques et des mélancoliques. L’Encephale, 34. (2008), 4. 322-329. DOI: https://doi.org/10.1016/j.encep.2007.06.006

Savopoulos, Priscilla - Anukka K. Lindell: Born criminal? Differences in structural, functional and behavioural lateralization between criminals and noncriminals. Laterality, 23. (2018), 6. 738-760. DOI: https://doi.org/10.1080/1357650X.2018.1432631

Shechory, Mally - Joshua M. Weiss - Rachel Weinstain: Differentiating Offenders by Index Offense and Personality Inventories: The Characteristics of Adult Probationers in Israel. International Journal of Offender Therapy and Comparative Criminology, 57. (2013), 3. 312-331. DOI: https://doi. org/10.1177/0306624X11428316

Sheehan, David V. - Kathy H. Sheehan - R. Douglas Shytle - Juris Janavs - Yvonne Bannon - Jamison E. Rogers - Karen M Milo - Saundra L. Stock - Berney Wilkinson: Reliability and Validity of the Mini International Neuropsychiatric Interview for Children and Adolescents (MINI-KID). Journal of Clinical Psychiatry, 71. (2010), 3. 313-326. DOI: https://doi.org/10.4088/jcp.09m05305whi

Sneyers, Michèle - Hedwig Sloore - Gina Rossi - Jan J. Derksen: Using the Megargee System among Belgian Prisoners: Cross-Cultural Prevalence of the MMPI-2 Based Types. Psychological Reports, 100. (2007), 3. 746-754. DOI: https://doi.org/10.2466/pr0.100.3.746-754

Tábori Kornél - Székely Vladimir: A bünös Budapest. Budapest, Tudáspolc, 2014.

\section{ABSTRACT}

\section{Criminal Psychiatry - Theoretical Background and Practical Applications} József HALLER - Mária Zsóka BELLAVICS - Noémi BARÁTH

The police have long relied on psychiatric knowledge, but criminal psychiatry, as a new discipline, has only recently emerged. In this study, we argue that police officers need to have knowledge in this area - not to become a psychiatrist, but to do a better job. This is justified by the fact that mental disorders are very common among offenders, as evidenced by our own research findings included in this study. After clarifying the basic concepts, we review (due to space constraints, only very superficially) the areas of law enforcement in which psychiatric knowledge could help the police officer, emphasising that our educational experience to date has shown that law enforcement students are receptive to such knowledge. Psychiatric knowledge of police officers cannot, of course, replace the work of psychiatrists - which would not be possible -, but it can make police work more professional.

Keywords: psychiatry, mental disorder, delinquents, law enforcement, professionalism 